\title{
THE FLOURISHING NATURE OF LABOUR BROKERAGE IN SOUTH AFRICA: AN INVESTIGATION INTO THE ROLE OF EMPLOYMENT AND PERFORMANCE UNCERTAINTY
}

\author{
Christie Schoeman* \\ University of Johannesburg \\ christies@uj.ac.za
}

Received: April 2015

\author{
Derick Blaauw* \\ North-West University \\ Derick.Blaauw@nwu.ac.za
}

Accepted: September 2015

\begin{abstract}
The objective of this article is to investigate the rationale behind the thriving nature of labour brokerage in specific labour market environments in general and, in particular, the flourishing nature thereof in South Africa. The factors and structures underlying labour brokerage are more complex than are generally assumed and propagated. This paper proposes an argument and explanation as to how non-price factors contribute to reasons behind the uncertainty to be employed and the existing underemployment. The uncertainty of employment enables labour brokers to appropriate rent and to profit from worker effort in the long run. In spite of the appropriation of rent, the presence and activity of brokers create employment at a discount wage for those who are not able to get a job. Labour brokers create jobs by profiting from uncertainty without impacting on the premium wage of insiders and the dynamics in a more secure formal labour market. A case study was done in South Africa to determine if the theory fits the sample.
\end{abstract}

Keywords

Labour brokers; employment; performance; uncertainty; underemployment

*DrC Schoeman is a senior lecturer in the Department of Economics and Econometrics, University of Johannesburg, South Africa. \#Prof PF Blaauw is professor in the School of Economics, North-West University, South Africa. 


\section{INTRODUCTION}

The factors that underlie long-run high, stable levels of unemployment ("underemployment") are more complex than is generally accepted and propagated. In general, studies and literature on unemployment focus on the macro role that economic or price-able factors such as economic growth, interest rates, wages, fiscal policies, monetary policies, hiring and firing costs, economic risk, productivity and skill shortages play in underemployment.

Research done on the nature of unemployment in South Africa indicates that unemployment results from not only economic factors and economic-related frictions in the labour market, but also non-price factors such as social and welfare variables and structures as well as power play (politics), which specifically culminate in a complex structure that results in uncertainty on employment, worker performance and in underemployment (Kingdon \& Knight, 200la; Kingdon \& Knight, 2001b; Schoeman, Botha \& Blaauw, 2010; Schoeman \& Blaauw 2009; Schoeman, Blaauw \& Pretorius, 2008). Non-price factors comprise institutional, cultural, political, social, welfare, and racial factors as well as historical and historic factors (Belot \& van Ours, 2001; Blanchard \& Philippon, 2004; Blanchard \& Wolfers, 2000; Bowles \& Gintis, 1990; Cabarello \& Hammour, 1997 amongst others). These "behavioural" factors originate and impact on employment, performance and wages from outside the labour economic domain and influence.

One of the symptomatic results of these factors that has recently attracted much attention and controversy in South Africa is labour broking. Labour broking was relative recently formally recognised and defined in South Africa in the Labour Relations Amendment Act of 1995 (Theron, Godfrey \& Lewis, 2005). In reaction to the increase in this labour practice, the Act was again amended in Act No. 6 of 2014, the Labour Relations Amendment Act, 2014, to provide: “... greater protection for workers placed in temporary employment services; to regulate the employment of fixed term contracts and part-time employees earning below the earnings threshold determined by the Minister; to further specify the liability for employer's obligations; and to substitute certain definitions; and to provide for matters connected therewith" (Government Gazette, August 2014, 59,37921 ). The hypothesis in the paper is that the flourishing nature of labour brokerage in South Africa (Kennelly \& Schmitz, 2000) is symptomatic of a dysfunctional and ineffective formal labour market and not a cause of underemployment in South Africa.

This paper focuses on the role played by the uncertainty of employment as well as that of contested exchange in wage formation in labour brokerage. The structures in contested exchange explain why labour brokers are able to appropriate economic rent in an uncertain labour environment. Non-price variables such as biased power and decisions motivated and based on non-economic factors do play a pertinent role in labour market uncertainty and contested exchange in the labour market (Bowles \& Gintis, 1990), as they do in the labour market in South Africa, which has been indicated by research (Deane, 2005; Fick \& High, 1987; Jones \& Inggs, 1994; Kingdon \& Knight, 200la; Kingdon \& Knight, 2001b), as well as in the uncertainty on employment (Schoeman et al., 2008). It is therefore probable that these factors are a cause of conflict, employment and performance uncertainty and contested exchange in the labour market, which then result in underemployment. 


\section{LITERATURE OVERVIEW}

\subsection{Introduction}

The literature relevant for this study stretches over a wide area in economic theory and is not limited only to labour economics. The approach is therefore to have a very general and concise overview on the relevant literature. This is to obviate the need to provide technical detail of the relevant content. The exposition of theory is done in this way to make the reasoning on labour brokerage accessible and the relevance of the theory and on the topic clear. These general insights into the different theories will be applied to support the argument in the paper.

As the title of the article suggests, uncertainty and the nature of uncertainty are real and form the framework for the argument. Uncertainty results from the manner in which information on outcomes is distributed in exchange and used in transactions. Different views exist on the complete nature of information and the degree of certainty with which economic decisions are taken, the manner in which decisions are made based on this and the (allocation) efficiency and the (cost) effectiveness of the outcome of these decisions (Summers, 1986). Uncertainty can be viewed in the first two propositions as randomness only in the future outcomes due to the exogenous variability in the environment assuming the world is existing out of a closed set of independent environments which all are known or can be known (Davidson, 1990; Savage, 1954). In this paper, this idea of uncertainty is referred to as irreducible but calculable risk. Uncertainty can also be viewed, as in the third proposition, as randomness in future states of the world, events and outcomes owing to variability of the environment within a world with an infinite of interdependent environments (Davidson, 2009; Davidson, 1990; Gerrard, 1995; Runde, 1990). In this paper, this type of uncertainty is referred to as true uncertainty in outcomes and opposite to risk (Davidson, 2009; Davidson, 1990).

Views on how people decide or have to decide can be based on the degree of uncertainty on and in the environment, which is generalised into three theories. In a generalised format, then, the first proposition on decision-making assumes certainty of outcomes and prescribes the axioms to be applied when ordering outcomes and consequences in an effort to maximise utility. A rational decision will choose the most preferred outcome out of a set of outcomes and consequences, and ensure that maximum utility is achieved via this process. The second proposition assumes either certainty in the probability of outcomes or, if there is uncertainty, then that a subjective probability can be calculated or computed from a closed set of different outcomes. A probability is either a given (as in the first proposition) or can be calculated. Values can be attached to the consequences of outcomes and the best-weighted outcome can be estimated for each event (Manski, 2008).

The probability of an outcome in throwing a dice or in playing the roulette wheel serves as an example where outcomes are randomly distributed and where probabilities are given (Anscombe \& Auman, 1963; Savage, 1954). Observing the outcomes when repeating an identical horse race (repeated experiment) serves as an example where outcomes are non-random and uncertain and calculation is needed to determine the probability of an outcome by using sample data from repeating an identical run. The probable outcomes become confined the more a run is repeated and the probability of a specific horse winning a race can be derived from actual achieved positions in the repetition. The unknown probability in the first race becomes better known to all punters the more an identical race is repeated. Information is either public or will eventually become publicly known among the punters. Manski (2008) proposes a third possibility when 
incorporating the role actuality plays in decision-making. This view is a descriptive theory, and deals with how agents in effect make decisions. It differs from the prescriptive (axioms ruling the order of preferences to maximise utility) and theoretical nature of both of the first two propositions on probability. Manski (2008) accepts the role of actuality in the spread and distribution of variables in decision-making, but still in a stochastic construct (Manski, 2008). Actuality bounds a so-called "rational" decision-maker in the real world, where events and outcomes are limited and not systematically repeated and where information on outcomes is incomplete. Decision-makers maximise utility in ignoring some of the axioms in considering and attaching values in a distribution and spread of actualised outcomes, consequences and events rather than considering all axioms, outcomes, consequences and outcomes as theory prescribes (Manski, 2008).

In these propositions information will surface and becomes public in exchange and transactions, either as a given or by way of calculations and computing. Superior knowledge of probability and values is of a short-run nature and gives the more informed agent or broker no advantage and therefore does not allow for the possibility of appropriating economic rent in the long run from "ignorant" agents. All information, at least in the long run, is known or at least knowable to all agents. However, Apreda (2001) makes a case for some agents profiting from asymmetric information in a world where the ability exists for some agents to be more informed than others. Asymmetrically distributed information is assumed as a given and real for worldly markets. Apreda (2001) does not explain, though, why this asymmetry in information is not resolved through exchange in a market - in other words, name the factors that will prevent arbitration and speculation in the long run and the reasons for the long-run presence of brokers to profit from appropriation rather than to profit from temporal undervalued and overvalued prices. The distinction between a broker and arbitrageurs and speculators is not clear. Specifically, the broker is able, unlike arbitrageurs and speculators, to act in a market and be dependent on the market but without impacting on market equilibrium and prices. In considering the first two propositions and that of Manski (2008) on actuality, information will become public in the end, i.e. information becomes public by normal economic processes of markets, namely arbitration and speculation by those with superior information. The opportunity to appropriate economic rent and profit from privately owned information disappears.

\subsection{The rationale for labour brokerage}

Brokerage is real and different from speculation and arbitrage only if it is possible to profit from superior information in the long run. To keep information superior it has to be possible to privatise information. To own private information is only possible under true uncertainty. Information can still be sold, but the search for, and gathering and processing of information in an uncertain environment is a timely and costly process (Diamond \& Dybvig, 1983).

In uncertainty and the asymmetrical distribution of information and power it is possible to profit from private information in exchange for services and thereby appropriate economic rent in the long run. This is so not because of the ignorance of agents but because of the cost of controlling and monitoring performance in a contract and collecting information to facilitate these actions in an environment of true uncertainty (Bowles \& Gintis, 1990; Diamond \& Dybvig, 1983). In terms of these inabilities, which flow directly from true uncertainty, Diamond and Dybvig (1983) rationalise the superior ability banks have to make deposits and loans liquid. Their reasoning is that the bank is able to keep track of the performance of a borrower at a low cost and control performance by keeping the history of performance and asking for collateral. By surveillance and 
monitoring of the action and performance of a borrower, a bank is accumulating information on performance at a relatively low cost, and this information is kept private and is not publicly available (Diamond \& Dybvig, 1983). The bank is in a better position to control and evaluate the risk of a borrower and/or client and to create credit and liquidity (Diamond \& Dybvig, 1983). The only information a bank has of a client of its competitor is that a client will only be willing to cross over at a rate lower than the actual risk, yet the bank still does not know the actual risk of the client. The cost of information in uncertainty creates a hurdle to the collection and entry of new entrants, creates short sides in markets and causes power to also play a role in the appropriation of rent (Bowles \& Gintis, 1990).

The third theory that is relevant for the argument in the paper rationalises and gives the reasons for the existence of an environment in which labour brokers flourish. Keynes's theory assumes that the probability of an outcome cannot be calculated and outcomes not parameterised in an uncertain environment (Davidson, 1990; Keynes, 1936). In the actual world a future value can in most instances not be attached to future outcomes. Outcomes are uncertain and this uncertainty cannot be resolved because of the sequential, interdependent and causal relationship between outcomes and their environment. In the actual world the distributions of outcomes, consequences and events are interdependent and continuously changing and this makes the probabilities incalculable. No stable structure exists which can determine the probability of an outcome. This theory proposes that order in exchange and the market and the structure and motives of decisionmaking in actual uncertainty are therefore different from those as proposed in an abstracted world, where probability is calculable and risk rather than true uncertainty exists (Gerrard, 1995; Knight, 1921; Keynes, 1920; Keynes, 1936; Runde, 1995 and Runde, 1990). According to Keynes (1936), convention and human nature in an uncertain environment rather than scarcity and the physical nature of goods prescribe the way in which reasonable decisions are made and goods and services are valued in an irreducibly uncertain environment. Information on outcomes and pricing are therefore purely the result of people's behaviour in a specific time and place. Human rather than physical nature determines the economy and economic outcomes: human behaviour in uncertainty is anchored by money prices, contracts discounted to money returns and expectations as well as bounded by the judicial framework and institutions and not by the physical environment and the economic reality (Davidson, 1990; Keynes, 1936). Knowledge on "... conventional valuation, the outcome of mass psychology" (Keynes, 1936:154) (sentiment) not only solves the uncertainty in outcomes in an uncertain world but makes exchange possible when the investor can profit from this superior knowledge on sentiment; "to beat the gun ... to outwit the crowd" to profit from the superior knowledge on when sentiment will change (Keynes, 1936:155).

The investor in his/her decisions, like the bookmaker in a once-off horse race, has to anticipate what the conventional valuation will be (choosing the overall favourite/fancy) and how it may change in the time prior to the race. This is not to anticipate the positions of the horses in the way conventional theory prescribes. He/she therefore has to determine the fancy of all other competitors rather than based the outcome on own expectations to jump the gun and to profit when favourites change. That is to follow the same principles to ensure success in betting in a beauty contest where agents betting are trying to determine what other competitors' opinions on the contenders are (Keynes, 1936:156). For the broker it is then to anticipate what competitors' opinions are on who the winner is going to be. In uncertainty, where no significance can be given to any variable which underlies beauty, when beauty lies in the eye of the beholder, then it is best not to bet on one's own opinion of beauty but to determine beforehand what competitors expect the average opinion on average beauty will be. This means making third-degree choices in "anticipating what average opinion expects average opinion to be" and by that "to beat the gun" 
to profit (Keynes 1936:155-156). This is totally different from the views prescribed and described by conventional theory on decision-making under uncertainty.

Bookmakers ("brokers") in a one-off horse race buy and sell illiquid lottery tickets prior to the race and profit through spreading buying and selling prices based on the betting sentiment. In liquidating horse race ("lottery") tickets (a ticket once bought and paid only performs / does not perform when a race is finished), brokers collect in a relative cheap way costly information on the sentiment in the market by monitoring the selling and buying of tickets and adapt prices accordingly to ensure a spread between prices to profit from this private information. Players in a liquid market can continuously change their positions as news changes and opportunities arise to manage the likelihood of loss or to profit as new information enters the market. This type of exchange actualises in the transacting and contracting which are based on mutual consent between agents, and motivated by profiting and minimising loss in taking new and better opportunities by reselling and buying in an uncertain open environment. These actions by brokers do not determine the outcome, the structure and dynamics in the formal race (market). The outcome depends on the natural abilities of the horses in the race. The need, objective and motivation to take part in this type of exchange may not be because of a love for horses or for the paper of a stock exchange, but may instead be a hedge against uncertainty in the future. Bookmakers and punters in general do not want to profit to buy horses in the race. Stockbrokers also do not want to buy grocery shops, for that matter, just as banks do not want to own factories. Economics lies behind the need, objective and motivation of all these decisions and creation of order. However, economic reality does not determine the dynamics and outcomes in this type and higher order of exchange and vice versa (Keynes, 1936).

Brokers practise the fourth degree of judgement in the forming of expectations when making decisions about sentiment and profit (Keynes 1936:156). In principle, the players bet on the horses in the race and the brokers on the players in taking up buy and sell positions at the same time on the basis of private information on market sentiment, on what players think the chances of the horses are. Based on this knowledge the broker profits from creating a spread between buy and sell prices on horses, spreads bounded and limited by the competition from other brokers. These actions from brokers make long-run illiquid lottery tickets liquid and outcomes less uncertain further down the line. This action makes it possible for contenders in an irreducibly uncertain environment to parameterise their likelihood of loss or to take up better opportunities to profit. By this action, the brokers and agents make the future manageable and expected rather than random and uncertain. The structure of and the dynamics in the formal race ("market") are not affected at all. The long-run outcomes in the market are not influenced by these actions. The order of exchange between brokers and players only supports a market that would otherwise fail or would not have existed at all. The labour broker acts as the merchant broker had acted many times in history, where the merchant broker would, next to the walls of a besieged city, keep up exchange to better the existing situation in the city, even long after exchange was supposed to fail at a very high cost for the city. The failing of exchange would leave the city with idle resources, which would have increased the wellbeing of the complete city. These are products that, like labour effort, are of value only when they or their creations can be exchanged.

Bidding and contracting in the labour market is flawed by uncertainty and is, in principle, synonymous with the uncertainty in the once-off horse race. By buying and selling labour contracts (instead of lottery tickets) and profiting from private information, in exchange the labour broker decreases the risk of contracting, making it possible for the employer and the worker to parameterise losses and to profit, thus stabilising the labour environment and market. In this 
process, the labour broker has no effect on the formal labour market and formal wage setting (official race and payout).

Along with the asymmetrical distribution of information in uncertainty, Bowles and Gintis (1990) introduce the role played by an asymmetrical distribution of power, which either puts a limit on or increases the appropriation of rent. The worker in the labour market knows the wage beforehand, as does the borrower in the money market, but the employer, like the lender, is uncertain about the performance of the worker in the money market, which only would be revealed after the worker is contracted (Bowles \& Gintis, 1990). The broker, like a bank, has an upper hand in his/her position of power in exchanging contracts in conditions of underemployment. The labour broker is, like a bank, able to do surveillance, monitor and keep track of the history of the performance of a worker. As is the case with banks in an uncertain money environment, labour brokers appear in reaction to and as a symptom of uncertainty in the formal labour market. As with banks, labour brokers have the ability to transform long-run contracts, which are irreversible and not transferable, into liquid contracts, by the buying and selling of contracts on the basis of private information. The labour broker is, again as is the bank, on the short side of the market and makes use of this position to determine the magnitude of rent, which can be appropriated. The fewer the brokers in exchange, the shorter their position in the market and the greater their power to appropriate rent.

For both the employer and the worker it is possible to change current positions in an effort to prevent the likelihood of loss. The loss for the employer occurs when he/she is unable to employ a worker or discharge a non-performing worker at low cost. The worker can make adjustments to prevent the loss when not employed in an environment of underemployment or to resign from an unwanted position at low cost. The broker creates the ability for the worker and employer to decrease uncertainty of a long-run contract and the likelihood of loss by the buying and selling of labour contracts (Bowles \& Gintis, 1990).

In the labour environment, uncertainty results from the endogenous nature of labour effort and performance, which is increased by non-priced factors that are present in exchange. Factors such as conflict, power struggles and the ability of a worker to control worker efforts and performance result in uncertainty in the exchange between worker and employer (Bowles \& Gintis, 1990). The latter ability of a worker causes uncertainty about the performance of a worker in the future. This causes uncertainty for the worker on being employed or re-employed in the future.

The buying and selling of worker contracts by a labour broker is beneficial for the employer in these conditions. Instead of directly controlling the worker and having to enforce effort at a high cost in an uncertain labour environment, the risk and uncertainty associated with a worker contract are carried over to labour brokers. The probability of losing from non-performance is smaller and that of performance higher.

The buying and selling of worker contracts by a labour broker are also beneficial for the worker. The more unavailable long-run contracts are for labour underemployment, the higher the uncertainty to be successfully employed, the higher the cost of being unemployed and the greater the advantages are for the unemployed to buy contracts from the labour broker. The premium price of a contract and a discount in wage is the price to be paid to avoid certain loss and to be able to put a value to future employment.

Through the selling and buying of labour contracts, the labour broker makes these contracts liquid and loss manageable and profit possible for both sides of the labour market. By buying and selling contracts, the broker can determine trend changes in the buying and selling of contracts, as in the 
buying and selling of lottery tickets in a once-off horse race. In buying contracts at low prices and selling them at high prices, the labour broker profits. By creating a market for labour contracts and making contracts liquid, in effect the labour broker prevents the formal labour market from failing because of true uncertainty. The labour broker thus makes it possible for both sides of the market to manage loss and to profit from uncertainty. The employer profits from performance and the worker profits by receiving a wage that would not be possible without the broker.

\section{METHODOLOGY}

The Contested Exchange Model ("CEM") of Bowles and Gintis (1990) has been deployed here to demonstrate that labour brokers have the incentive and ability to privatise information in an uncertain formal labour market characterised by high, stable levels of unemployment or underemployment. In short, this would imply an ability to profit directly from private information in an uncertain labour environment. With this aim, the CEM is extended to rationalise a theoretical role for labour brokerage in uncertainty in the labour environment. Uncertainty is the result of the endogenous nature of labour effort, the high cost of monitoring effort and the ability of an employer to force down its objectives in an environment of underemployment (Bowles \& Gintis, 1990).

In the CEM wage, worker effort, production and profit are not determined only by own interest and utility maximisation, as in the neo-classical model. Wages and profit are the result of the power struggle in the exchange between the employer, on the one hand, and the worker, on the other hand, in a competitive equilibrium. The exogenous variables - that is, economic reality as described above - limit but do not determine outcomes. It is then demonstrated that, in effect, a broker brings greater certainty to contested exchange. Through this role, labour brokers make profit as well as wages externally determined and more efficient, market discipline (rules) externally enforced and more effective and contracts more complete.

These characteristics and the role of the broker in contested exchange are then compared with a short narrative on the dynamics that underlie the changed labour market structure and labour environment in South Africa. The aim of such a narrative is to investigate the applicability of the CEM and its propositions in explaining the flourishing nature of labour broking in South Africa.

\subsection{A model to explain labour brokerage}

The pricing of labour effort in contested exchange in the labour market is formally structured and demonstrated in the CEM of Bowles and Gintis (1990). It is assumed in the CEM that worker effort is endogenously determined by the worker and that effort is costly for the worker, valuable for the employer and costly to measure and monitor. It is assumed that an employer can terminate the contract of a worker as a penalty for non-performance, as stipulated in a contract.

The termination of a contract is costly for the employer in that it may take time to search for and employ another worker. The cost of the termination or non-renewal of the contract for the worker depends on the gap (employment rent) $v(w)-z(\bar{w})$, the difference between the current value the worker attached to not being re-employed $v(w)$ and a given minimum value $Z$ at which the worker is indifferent to being employed or not (Bowles \& Gintis, 1990).

The current value of employment $v(w)$ is the sum of future wages discounted by the effort needed $e$ to secure the job. The minimum value the job has for the worker or fallback position is $z(\bar{w})$, 
where $(\bar{w})$ the wage is at a different job but an equal job opportunity. By implication, it is a wage determined in a competitive market (Bowles \& Gintis, 1990). The reservation wage $(\bar{w})$ is discounted by the cost of not being re-employed and $z$ is the value that makes the worker indifferent to being employed or not employed by the specific employer. All effort in excess of this minimum effort contracted for $\bar{e}$ at a given wage $w$ is costly for the worker (Bowles \& Gintis, 1990). The larger the employment rent $v(w)-z(\bar{w})>0$ the more costly it becomes for the worker to be dismissed and unemployed. The implication is that a wage above $\bar{w}$ increases labour effort to prevent dismissal and the relatively higher cost of unemployment (Bowles \& Gintis, 1990).

The total value of employment $v$ is thus equal to total utility $u(w e)$ from being employed, plus the expected value of being re-employed $f(e) v$, plus the expected cost of dismissal $1-f(e) z$ (Bowles \& Gintis, 1990). It is assumed that the worker will choose $e$ to maximise the value of employment. The worker will thus choose $e$ at each given level of wage $w$ in such a way as to maximise his/her value of employment $v$. This will be where the marginal dis-utility (cost) of effort $u_{e}$ equals employment rent $-f_{e}(v-z)$, which is the best response of the worker at a given wage (Bowles \& Gintis, 1990). The best response for the worker to a given change in wage is to match such a change with an equal change in effort to ensure optimal employment rent. These responses to a given wage form the extraction (response) function of the worker. This is the best response for a worker in sacrificing effort at a given wage (Bowles \& Gintis, 1990:179, 213). In line with the Stackelberg model on price-leadership, it is assumed that the employer has complete knowledge on the response function of a worker (Bowles \& Gintis, 1990). Although the worker has complete information on the objective function of the employer, the worker is only able to choose an optimal wage at a given objective function. This is due to the inability of the worker to use the power invested by endogenous effort to appropriate a larger labour rent in the presence of underemployment (Bowles \& Gintis, 1990).

Due to the optimal nature of the response function $\frac{d e}{d w}$, effort $e$ increases with an increase in wage but at a diminishing rate. The maxim is that the greater the effort by the worker and the smaller the probability of dismissal, the costlier the increase in effort and the smaller the response to an increase in wage. This explains the non-linear reaction of the worker to higher wages and the nonlinear form of the response function of the worker $r_{1}$ in FIGURE 1 .

The steepness of the response function of the worker depends on the sensitivity of the effort of the worker towards a change in wage. The sensitivity of the worker depends on the probability and cost of dismissal. It is assumed that the more power a worker has, the less the probability of dismissal at a given wage, the less sensitive worker effort is to a change in wage and the flatter the response function is (and vice versa). This explains the nature of the respective response functions $r_{1} ; r_{2}$ and $r_{3}$ in FIGURE 1 .

The employer maximises return where the marginal effect on effort of a wage increase $e_{w}$ equals the average effort per unit of wage cost $e /{ }_{w}$ (Bowles \& Gintis, 1990:180). All these points have the same effort per wage and form the objective function $(e / w)^{*}$ of the employer in FIGURE 1 .

The slope of objective function of the employer $(e / w)^{*}$ depends on the relative change in effort $e^{*}$ to a change in wage $w^{*}$ or $e^{*} / w^{*}$. The slope $e^{*} / w^{*}$ depends on the ability of the employer to monitor contracted effort, the power the employer has in the market, as well as on the power the worker has to appropriate rent in the exchange of effort for employment in the market without being dismissed. 


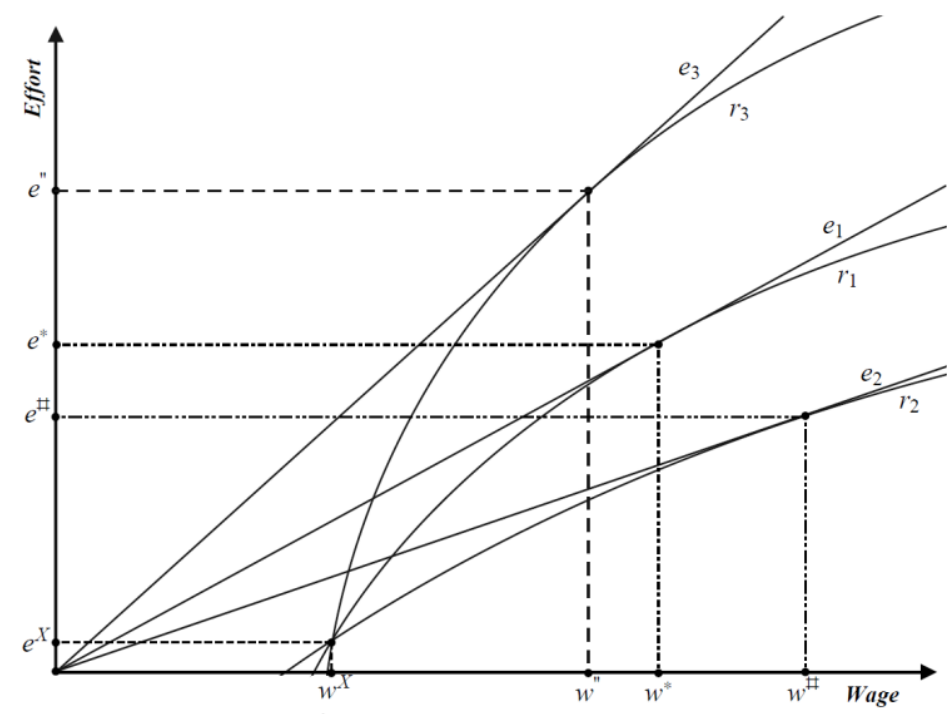

\section{FIGURE 1: The pricing of labour in a contested market}

Source: Authors' adaptation of the Stackelberg Model of Price-leadership as in Bowles and Gintis, 1990

In general, the employer assumes that an increase in the wage paid for effort will be exchanged for more effort by the worker (and vice versa). The ability to monitor both effort and worker power influences the decision of the employer regarding technology and the objection function of the employer. The technology to be used prescribes the optimal effort-wage in maximising profit and determines the slope of the objective function. The steeper the slope, the more capital-intensive the technology and the less the ability of the worker to appropriate labour rent in exchange for effort.

Owing to the cost of dismissal, the worker provides a greater level of effort in the presence of an employment rent $e^{*}>\bar{e}$, as would have been the case in the absence of monitoring. Control of effort is thus effective in the presence of an employment rent because of the cost of being unemployed. The worker also now receives a wage greater than the reservation (going market) rate $w^{*}>\bar{w}$. The implication of an employment rent is that the labour market does not clear because of an ineffective wage. Enforcement of effort from labour by means of an employment rent results in a decrease of labour market effectiveness at the cost of outsiders. Further cost for the labour market lies in the use of non-optimal and ineffective technology. Technology is not exogenous and a given in the objective function of the employer, but depends on the ability of the technology to give the employer the means to measure and enforce effort rather than effectivity in production. Factors other than the economic factors that motivate production include the decisions of the employer, which create underemployment in the labour market.

Contested equilibrium in FIGURE 1 depends on the objective function (technology), which the employer decides on, and the response function of the worker, which is known to the employer. All response functions in FIGURE $l$ start at the minimum wage $\bar{w}$ for a minimum of effort $\bar{e}$, the rate without any endogenous enforcement on contracts and the going market rate for employment. This position is analogous to the classical equilibrium wage in a competitive market. The employer maximises profit given the response function of the worker. In this way, contingent equilibria for 
the renewal of contracts for all different objective functions (technologies) can be determined. In FIGURE 1 , the equilibria are given the respective response functions: $r_{1} ; r_{2}$ and $r_{3}$ of a worker are $e^{*}=w^{*} ; e^{\#}=w^{\#}$ and $e^{"}=w^{\prime \prime}$.

In considering the role of power in FIGURE 1 , the lesser the power of a worker is owing to underemployment, the larger the probability of dismissal is at the going market wage rate $\bar{W}$ and the lesser the control a worker has over his/her own effort. This implies that more units of effort will be sacrificed for a unit of wage and that the trade-off will be larger between effort and exchange for an increase in wage, as reflected by $r_{3}$ (Bowles \& Gintis, 1990). The opposite occurs in $r_{2}$ when a worker is supported by a labour union.

In considering the role of uncertainty in FIGURE 1, the more knowledge exists on the response function of the worker, combined with the power of enforcement of effort in underemployment, the greater is the ability of the employer to dictate the technology and the point of production most favourable for her/him.

\subsection{A rationale for the development and existence of labour brokerage}

In the presence of underemployment, an unemployed worker as an outsider does not have the power and ability to use effort to ensure re-employment, as the insider is able to do. No employment rent $v(w)$, no fallback value $z(\bar{w})$ and no income exist for the outsider. No information exists for the unemployed worker to calculate a probable employment value $v$ or a fallback value $z$ when unemployed. In terms of information, the outsider worker finds herself/himself in the irreducibly uncertain position of the player betting on a once-off horse race. No value can be attached to an employment opportunity in the future.

In such a situation, where the outsider would be excluded in the absence of a broker, the broker can now play a role in getting outsiders job opportunities. The broker does so by making labour contracts (lottery tickets) enforceable and liquid by acting as a market maker as banks do in the market for credit, as discussed in section 2. The labour broker's actions in an uncertain labour market are, in principle, the same as that of the bookie in a once-off horse race. Instead of buying and selling long-run lottery tickets and thereby increasing their liquidity and enforcement, the labour broker is buying and selling labour contracts.

In the presence of underemployment, the broker is able to buy effort from an outsider at a wage lower than the fallback wage for effort $\bar{w}$. The broker then sells the labour contract to an employer. The motivation of the broker is to profit from private information on the ability of a client to perform and on the ability of the broker to penalise non-performance by non-renewal of a contract.

A dual market in effect develops in an uncertain labour environment characterised by a power bias in contested exchange, ineffective wages and underemployment. There is a market for insiders with relative high wages in a highly regulated environment and one for appropriated outsiders - a highly active but unregulated market. In FIGURE $1 r_{2}$ represents the worker reaction function in the formal insider market and $r_{3}$ represents labour's reaction function in the unregulated outsider market. The labour broker's profit is reflected in the difference in wage paid for $e^{\#}$ units of effort in the formal market $w^{\#}$ and $w^{\prime \prime}$ paid by labour brokers for outsider effort. This illustrates that, under the assumptions made - biased power in exchange, ineffective wages and underemployment - it is possible for a labour broker to profit (receive economic rent) from private information. The inability of the worker to attach a value to future employment is bridged 
by accepting a discount on wage. The outsider in effect supplies more than market-related effort in exchange for a job.

\section{CONTESTED EXCHANGE, LABOUR MARKET UNCERTAINTY, CONFLICT, UNDEREMPLOYMENT AND THE DEVELOPMENT OF LABOUR BROKERAGE IN SOUTH AFRICA: 1970-2013}

The choice of the specific time period for the narrative is in line with previous evidence that the seventies signalled the start of worker militancy and a gradual change in the bias of government in favour of the worker to a more balanced worker environment (Schoeman et al., 2010; Van der Velden \& Visser, 2006). The developments and changing dynamics in the labour market since 1970 may have, as is proposed in this paper, prepared the substrate needed for the flourishing nature of labour brokerage in South Africa. The gradual shift in the balance of power in favour of the worker started in 1973. This period was marked by unusual demonstrations by workers in the Natal textile industry. At the height of the strikes, an estimated 60000 to 100000 black employees from the brick, textile, chemical, rubber, iron and steel industries and the electricity and municipal services in Durban and surrounding areas were involved (Van der Velden and Visser, 2006). In response to the demonstrations, provision was made for a committee of non-union representation at the individual enterprise level (Schoeman et al., 2010).

More interventions followed and, in 1977, the government appointed the Wiehahn Commission to enquire into labour legislation in general in South Africa. The bulk of the Commission's proposals were accepted. The report included suggestions on the lawful registration of black trade unions and the eradication of legislated job reservation (Van der Velden \& Visser, 2006). The inclusion of the proposals in the Labour Relations Act in 1979 signalled the onset of the growth of black trade union movements and their political influence (Schoeman et al., 2010).

The increased regulation of the labour market gave the workers a strong foundation, not only to negotiate better wages but also to drive political goals (Jones and Inggs, 1994). By the end of 1977, between 55000 and 70000 workers out of a total black workforce of 7 million were believed to belong to 27 unregistered black trade unions, representing about one percent of the total black workforce. The 1980s were characterised by bigger institutional build-up in favour of the unskilled worker, primarily to resolve labour conflict through business by renegotiating the worker's share in production (Schoeman et al., 2010). By 2005, the number of trade union members had grown to about three million, representing almost 40 percent of the formally employed labour force, excluding the agricultural sector, domestic workers and self-employed persons. This amounts to an annual increase of nearly six percent. According to the International Labour Organisation (ILO), this constituted the greatest increase among the 92 countries annually surveyed in the ILO's study of the world's labour markets (Barker, 2007:93). Labour unions such as the National Union of Mineworkers (NUM) grew rapidly from the 80 s and steadily became more militant, culminating in a three-week strike in 1987. The intensity of the conflict and militancy of the union is reflected in the fact that nine people were killed and 500 were injured during the strike (Schoeman et al., 2010). At the same time, unemployment grew as uncertainty also increased with growing disinvestment and the deterioration in the overall economic and political environment in South Africa (Schoeman \& Blaauw, 2009).

In a relatively short period, the unions, led by the Congress of South African Trade Unions (which represented both industrial and general worker unions under one umbrella), developed into a 
fearsome economic and political entity (Schoeman et al., 2010). The change in the political dispensation in 1994 gave extra impetus to the union in the form of government's alliance with the worker, greater political intervention and the introduction of minimum wages, social charges on payrolls and job protection through legislation (Kingdon \& Knight 200 la:5-6; Kingdon \& Knight, 2001b).

The relatively quick and radical changes in the field of labour created a lot of uncertainty for business about labour. These changes included the militancy of workers, newly formed unions, the rapid development of unions into formidable political and economic forces, the historical absence of a formal collective framework to handle conflict between workers and business and the political nature of the labour conflict (Schoeman et al., 2010). History also did not leave workers with much reason to trust business. The increase in overall uncertainty and high levels of employment were aggravated by the historical adverse shocks of increasing political instability, the debt crisis, sanctions, disinvestment, increased internal war efforts and the beginnings of globalisation. In the same period, unemployment increased exponentially, while capitaldeepening increases were financed by periodic negative real interest rates (Schoeman et al., 2009; Schoeman et al., 2010).

The changed structure and dynamics in the South African labour market since 1970 can, with hindsight, be illustrated in FIGURE 1 by a shift of the worker reaction function from $r_{1}$ to $r_{2}$, with a subsequent increase in the unit price for effort. The significant increase in unemployment owing to capital-deepening and union militancy (Schoeman et al, 2010) created an opportunity for broker intervention in an outsider market. Power struggles and conflict in the formal market created underemployment and uncertainty about the ability of a worker to be employed in the future and an increase in the possibility of loss of what is currently owned. It is possible for labour brokers to profit from the uncertainty and possible loss in underemployment, as it was possible for brokers to profit and thrive in uncertainty and possible loss next to the walls of besieged cities in the past. Ultimately, these brokers prevent the total collapse of the economies in these cities.

High and stable levels of unemployment lead to the development of a dualistic labour market. It develops from an initial very unstructured and unsophisticated market to a highly structured and sophisticated informal market. One finds a market for insiders with relative high wages in a highly regulated environment and one for appropriated outsiders - a highly active but unregulated market. $r_{2}$ in FIGURE 1 represents labour's reaction function in the formal insider market and $r_{3}$ represents labour's reaction function in the unregulated outsider market. The labour broker's profit is reflected in the difference in wage paid for $e^{\#}$ units of effort in the formal market $w^{\#}$ and $w^{\prime \prime}$ paid by labour brokers for outsider effort. This illustrates, in the given limited structure and assumptions made, that, owing to the changing dynamics in the labour market since 1970, a situation may have developed, and may even presently exist, in South Africa that makes it possible for labour brokers to appropriate profit, even in the long run, from a specific group of workers in the labour market.

It seems a high degree of consent exists between researchers in this field of labour that the inelasticities in the labour markets stem from labour laws that restrain the employment of labour and labour creation. Originally, these laws were introduced and aimed to have the opposite result. In theory, these laws in effect had to create a framework in which the worker and the employer relation were regulated to make conciliation possible and the labour market free of long-run and ongoing conflict. In this way, it makes it possible for employer and worker to structure their risk and to create an environment of certainty and one free of long-run conflict. The misuse of power and the biased and arbitrary ways in which these laws are interpreted and executed rather than 
the framework itself seem to have created the current environment of long-run and ongoing conflict in the labour market. This conflict, rather than the labour laws per se, restrains employment creation (Schoeman et al., 2010). Labour broking in South Africa is a result of the conflict in the labour market and does not contribute to greater unemployment or the conflict in the formal labour market. Labour brokerage, in effect, contributes to the employment of workers outside the formal labour market and makes it possible for those who do not share in labour income, and would otherwise not share, to share in it. The cost these outsiders pay is the cost that flows from power bias, ineffective wages and the ongoing labour conflict in South Africa.

The risk for employers, though, becomes indeterminate when labour unions do not operate in the spirit of this framework by virtue of their increasing militancy (Schoeman et al., 2010). This has resulted in reaction from employers and conflict without any real attempt from government to make irresponsible behaviour costly, and it has also created certainty for employers. It was left to the courts (and, very recently, only in Act No. 6 of 2014) to take responsibility for this as a last resort to do just that in the spirit of the Constitution and not to leave it to politics.

\section{CONCLUSION}

The objective of this article was to investigate the rationale for labour brokerage in specific labour market environments and the flourishing nature thereof in South Africa. The hypothesis was that labour brokering is a symptom of and conditioned by the role played by non-price factors and uncertainty in a contested labour market.

This paper found that a contested labour market environment that is characterised by power bias, ineffective wages, high labour rent and underemployment is the reason for the flourishing nature of labour-brokerage in South Africa. The labour broker has the incentive and the ability to appropriate long-run profit from the outsider to the formal labour market in the presence of underemployment. The outsider exchanges effort for a job at a discount wage and offers larger than market-related effort in exchange to be able to put a value to a job in the future. The spillover effects of such action for the economy are a relative increase in labour effort, decreased underemployment and an increase in the wealth of workers in general.

A narrative on the historical dynamics in the labour market of South Africa fits the conditions, structure and findings of the CEM model and rationale for the development of labour brokerage in general as proposed. The model is successful in giving both a theoretical and a viable qualitative explanation for the flourishing nature of labour brokerage in South Africa. For more robust and unambiguous results, the theoretical proposed structure and findings would have to be quantified and tested for South Africa.

\section{LIST OF REFERENCES}

Apreda, R. (2001). The brokerage of asymmetric information, CEMA Working Paper Series, 190.

Anscombe, F.J. \& Auman, R.J. (1963). A definition of subjective probability. Annals of Mathematical Statistics, 34, pp. 199-205.

Barker, F. (2007). The South African labour market, $5^{\text {th }}$ edition. Pretoria: Van Schaik. 
Belot, M. \& Van Ours, J.C. (2001). Unemployment and labour market institutions: an empirical analysis. Journal of Japanese and International Economics, 15, pp. 1-16.

Blanchard, 0. \& Philippon, T. (2004). The quality of labour relations and unemployment. NBER Working paper, 10590. Cambridge: The National Bureau of Economic research.

Blanchard, 0 . \& Wolfers, J. (2000). The role of shocks and institutions in the rise of European unemployment: the Aggregate Evidence. The Economic Journal, 110, pp. 1-33.

Bowles, S. \& Gintis, H. (1990). Contested exchange: New micro foundations for the political economy of capitalism. Journal of Politics and Society, 18, pp. 165-222.

Cabarello, R.J. \& Hammour, M.L. (1997). Jobless growth: appropriability, factor substitution and unemployment, NBER Working Paper, 6221. Cambridge: The National Bureau of Economic research.

Davidson, P. (1990). Uncertainty in economics: Keynes, knowledge and uncertainty, Journal of Economic Perspectives, 5(1), pp. 107-116.

Davidson, P. (2009). Risk and uncertainty in economics. Paper presented at the Conference on the Economic Recession and the State of Economics. London: Westminster.

Deane, T. (2005). Affirmative Action: A Comparative Study. Unpublished Doctoral thesis in Law, Pretoria: UNISA.

Diamond, D.W. \& Dybvig, P.H. (1983). Bank runs, deposit insurance and liquidity. Journal of Political Economy, 91(5), pp. 401-419.

Fick, R. \& High, S.H. (1987). The theory and practice of industrial relations in South Africa. Bergvlei: Hodder and Stoughton.

Gerrard, B. (1995). Probability, uncertainty and behavior: a Keynesian perspective. In S. Dow \& J Hillard (eds.), Keynes, knowledge and uncertainty. Aldershot: Edward Elgar.

Jones, S. \& Inggs, J. (1994). An overview of the South African Economy in the 1980's. South African Journal of Economic History, 9(2), pp. 1-18.

Kennelly, V. \& Schmitz, G. (2000). An analysis of the labour brokerage industry of South Africa. Research Report, Graduate Business School, University of Cape Town.

Kenny, B. \& Bezuidenhout, A. (1999). Contracting, complexity and control: An Overview of the changing nature of subcontracting in the South African Mining Industry. The Journal of the South Africa Institute of Mining and Metallurgy, July/August, pp. 185-191.

Keynes, J.M. (1920). Treatise on probability. Reprint 1989. London: MacMillan.

Keynes, J.M. (1936). The general theory of employment interest and money. London: MacMillan

Kingdon, G. \& Knight, J. (2001a). What have we learnt about unemployment from micro datasets in South Africa? Centre for the study of African economies, Department of Economics, Oxford University.

Kingdon, G. \& Knight, J. (2001b). Why high open unemployment and small informal sector in South Africa? Centre for the study of African economies, Department of Economics, Oxford University.

Knight, F.H. (1921). Risk, uncertainty and profit. New York: Houghton Mifflin.

Manski, C.F. (2008). Partial prescriptions for decisions with partial knowledge, NBER Working Paper, 14396. Cambridge: The National Bureau of Economic research.

Runde, J. (1990). Keynesian uncertainty and the weight of argument. Economics and Philosophy, 6, pp. 275-292. 
Runde, J. (1995). Risk, uncertainty and Bayesian decision theory. In S. Dow \& J Hillard (eds.), Keynes, knowledge and uncertainty. Aldershot: Edward Elgar.

Savage, L.J. (1954). The Foundations of Statistics. New York, Wiley.

Schoeman, C.H, Blaauw, P.F. \& Pretorius, A.M. (2008). An investigation into the determinants of the South African unemployment rate, 1970-2002. Acta Academica, 40(3), pp. 67-84.

Schoeman, C.H. \& Blaauw, P.F. (2009). Unemployment in South Africa 1970-2002: the development of a configuration concern for future employment. Journal of Economic and Financial Sciences, 3(1), pp. $87-98$.

Schoeman, C.H., Botha, I. \& Blaauw, P.F. (2010). Labour conflict and the persistence of underemployment in South Africa. South African Journal of Economic and Management Sciences, 13(3), pp. 272-292.

Slabbert, K. (1999). The future role of trade unions in South Africa, Aambeeld, November. Johannesburg: Rand Afrikaans University.

Summers, L.H. (1986). Does the stock market rationality reflect fundamental values. The Journal of Finance, 41(3), pp. 591-601.

Theron, J., Godfrey, S. \& Lewis, P. (2005). The rise of labour broking and its policy implication. Development and Labour Monograph 1/2005.

Van Der Velden, S. \& Visser, W. (2006). Strikes in the Netherlands and South Africa, 1990-1998: a comparison. The South African Journal of Labour Relations, 30(1), pp. 51-75. 